\title{
A COMPARISON OF SUBJECTIVE QUALITY-OF-LIFE INDICATORS ACROSS DOMAINS OF JEWISH SENIORS LIVING IN THE COMMUNITY
}

\section{Sue Parton \& Sulina Green}

"Constructing a collective, inclusive, dignity-affirming meaning for the latter part of life will come when the voices of older people, speaking for themselves, are salient" (Witkin, 2000).

\section{INTRODUCTION}

This paper sets out to describe the comparisons of subjective quality-of-life indicators across domains that enable Jewish older persons - and, in particular, those who are members of Cape Jewish Seniors Association, Milnerton ${ }^{1}$ - to remain living in their communities. From the outset, and for the purpose of this paper, two concepts need clarification. Firstly, the term "Jewish" pertains to any one who professes to be Jewish either through birthright or religious conversion, and who consider themselves Jewish, irrespective of their frequency of attendance at a place of worship. It also pertains to any person of Hebrew descent (Barnhart \& Barnhart, 1987:1132; Lamm in Donin, 1991:8). Secondly, the terms "seniors", "aged" and "older person" are used interchangeably and will be used to denote people aged 60 and over. The Older Persons Bill, South Africa, defines older persons as women and men aged 60 and 65 respectively ( Ministry for Welfare \& Population Development, 2003:3). ${ }^{2}$

The Cape Jewish Seniors Association (CJSA) was established in response to the social needs of the Jewish older person (Stein, 1986) and has been in operation for 21 years. There are a total of four branches in the Cape Peninsula; the older, more established branches are found in Seapoint (parent branch and head office), followed by Claremont and Muizenberg. The fourth branch, found in Milnerton, was formally launched at the beginning of 2002 as a consequence of the increasing numbers of Jewish seniors moving into the northern suburbs of Cape Town.

Nationally, the Jewish community accounts for less than $0,2 \%$ of the total population of South Africa's estimated 48 million people and can be said to constitute an ethnic minority (Statistics SA, 2001a, 2001b). Since the 1970s the South African Jewish population has experienced an overall decline of some $36 \%$ and at present has an estimated total population of 85,5000 (Kaplan, 2006). Three surveys undertaken in 1991, 1998 and 2005 point towards an ethnic minority who view themselves as being both Jewish and South African and highly assimilated (Dubb, 1994; Kaplan, 2006; Kosmin, Goldberg, Shain \& Bruk, 1999).

Of interest to this research is that nationally the total number of older persons aged 60 and over make up 7,3\% of the total population in South Africa across all race groups. By comparison, in the Western Province 10,8\% of all race groups are aged 60 and over, increasing to 18,7\% for the white population and 27,6\% for the Jewish population (Department of Social Development, n.d.:8-9; Statistics SA, 2001a, 2001b, 2001c). The figure thus given for the Jewish aged population in the Western Cape is double the provincial norm for all race groups, $10 \%$ higher than the white population and almost four times the national average These figures have a bearing on long-term planning for the Jewish aged in the Western Cape.

\footnotetext{
${ }^{1}$ A faith-based volunteer community centre which caters specifically for Jewish Seniors aged 60 and over, and who were paid-up members for 2006. The branch under study is located in the northern suburbs of Cape Town.

${ }^{2}$ Usually the terms of reference are country-specific and relate to age of retirement (Legare, Ibrahima, Sossa \& Smuga, 2003; WHO, 2000:10).
} 
The South African government, cognisant of worldwide population ageing trends, ${ }^{3}$ formulated its policy on older persons by drawing upon the international guidelines as laid down in the Second World Assembly on Ageing, viz. the Madrid International Plan of Action on Ageing, 2002. One of the stipulated priorities mentioned is the need to ensure enabling and supportive environments for the older person by means of developing support systems that would "enhance ... self reliance of older women and men and create conditions that promote quality of life and enable them to work and live independently in their own communities for as long as possible and desired" (UN, 2002:29).

A similar theme is evident in the Older Persons Bill (2003), which recognised, inter alia, the access of older persons to "health, welfare and other care and support systems" in order for them to "live with dignity within the community" ( Ministry for Welfare \& Population Development, 2003). While a paradigm shift from the macro to the micro level is all too evident, what needs to be explored is the social capacity of seniors to age in place and to live in the community for as long as possible. Inextricably linked to this is how the Jewish seniors perceive their quality of life and what enables them to remain living in the community. What is more, the unique demographic characteristic of Jewish older persons, coupled to the future spectre of population ageing, lends itself to further exploration.

In the light of limited available literature and data sets pertaining to (South African) Jewish seniors, the central thrust of this paper sets out to describe the comparisons of self-reported quality-of-life indicators across various domains. The purpose of the research at the next level is to impact effectively on the medium- to long-term planning of the organisation in question, where such planning is age- and need-specific. It is further hoped that the findings of this research will have wider implications in terms of policy decisions by other Jewish service organisations committed to the aged in Cape Town.

\section{PROBLEM STATEMENT}

The government's contention that "there is ... an inappropriate emphasis on the Government's responsibility for the care for the aged" shifts the burden of support from central government to community support services and local authority and, by extension, to the informal sector. Thus while the South African government shares the concern of population ageing with the rest of the world, as is evidenced by its formulation of the Older Persons Act of 2006, there still remains a critical lack of information on both informal service providers and issues surrounding older persons (Ministry for Welfare \& Population Development, 1997; WHO, 2000; WHO, 2002:7). This critical lack of information is extended to the Jewish population and in particular Jewish seniors, particularly to the way that they view their quality of life, and the way this serves to anchor older persons within their social milieu.

\section{GOAL OF RESEARCH}

Following from the above, the overall goal of this paper is to gain a better understanding of quality-of-life indicators of Jewish seniors, which promote the quality of their lives and enable them to live independently within the community.

\footnotetext{
${ }^{3}$ The White Paper on Social Welfare (Ministry for Welfare and Population Development, 1997:86) sounded a warning that the projected population of senior citizens in absolute numbers will total 3,4 million by the year 2015. Further projections state that by 2050 older persons in both the developed and developing nations will comprise an estimated 33\% of their total populations or a total of two billion (Kinsella \& Velkoff, 2001; UN, 2006).
} 


\section{RESEARCH METHODOLOGY}

In order to better understand the social context plus the quantitative nature of the research topic under study, both qualitative and quantitative research approaches were used (Grinnell, 1985:121, 263; Grinnell, Tutty \& Williams, 2005:86-87; Rubin \& Babbie, 1993:30; Terre Blanche \& Durrheim, 2002:40).

The research design employed for the purpose of this study is a non-experimental, crosssectional survey design using a survey research strategy where the data was exploratory/descriptive. This research was further informed by a literature review which examined the following areas: (a) population ageing; (b) quality-of-life indicators of the older person; and (c) social support networks as related to systems theory.

The population of 134 members is drawn from the following areas: Bloubergrant, Bloubergrands, Bothasig, Brooklyn, Century City, Century View, Edgemead, Greenpoint, Lagoon Beach, Milnerton, Oranjezicht, Parow (including Parow East and North), Rugby, Sunningdale, Tableview, Tygerhof, West Beach, Woodbridge Island and Woodstock. It must be noted that members who attend from Greenpoint, Oranjezicht, and Woodstock are the exception rather than the rule, as CJSA has a branch in Sea Point.

A set of pre-conditions served to develop the sample frame of 112 Jewish seniors aged 60 years and over. Using simple random sampling, an initial sample size of 30 was selected. The sample size was based on Grinnell and Williams's (1990) assertion that 30 is sufficiently large, as the research population is small and fairly homogenous (Strydom, 2005:210-211), which in turn lends itself to smaller sampling error and thus greater representativeness.

Twenty-four of the would be-participants gave informed consent while six declined, reducing the number of participants, and sample size, from 30 to 24 . However, it was felt that to maintain the integrity of the research study it was preferable to state this as a limitation of the study rather than compensate with the sample frame. Attention is drawn to the exceptionally good response rate of $80 \%$, which is indicative of the representativeness of the sample (Babbie \& Mouton, 2003:261).

In order to ensure a higher response rate and higher representativenss, the research instrument of choice was face-to-face interviews using an interview schedule that was structured and which made use of both closed and open-ended questions (Babbie \& Mouton, 2001:250; Sheridan \& Kisor, 2000:112-113 ). All but one interview took place in the participants' homes. One interview was an office interview as the participant could not be assured of privacy in their home.

The code of ethics governing research practice in the field of gerontology does not differ widely from other fields of research. ${ }^{4}$ As the population is made up of Jewish seniors, a proportion of whom may have experienced the Holocaust, special consideration had to be given to avoiding emotional distress and harm (Sheridan \& Kisor, 2000:122). Care was taken that, in dealing with the older seniors, the questionnaires would be readily understood and that the duration/length of the interview would not be too onerous.

4 Key to which is the principle of informed consent and confidentiality, where requested. 


\section{THEORETICAL FRAMEWORK}

\section{Systems theory}

According to the literature, social support in old age is one of the most important domains as it serves not only as a buffer against associated losses, but also has positive effects across a wide range of outcomes such as quality of life, health, wellbeing, morbidity and mortality rates (Bowling, 2005:102; Carroll \& Whelan, 1994:4; Gabriel \& Bowling, 2004; Harrigan \& Farmer, 2000:51; Qureshi, 1990:32-39; Siebert, Mutran \& Reitzes, 2000:101). This section gives a brief theoretical overview of social support systems of the older person as conceptualised by the systems theory approach.

Support systems have been described as being informal, quasi-formal and formal, and when applied to the elderly, are largely defined by the proximity of the affective relationships to the older person as well as the "degree of bureaucracy of those relationships" (Cantor \& Little, 1985). ${ }^{5}$ Central to this theory is the model of substitution whereby the older person would seek help first from his/her informal social network and only then turn to the formal network in what Cantor has termed the "hierarchal compensatory theory of social support" (Cantor \& Little, 1985:746; Zodikoff, 2003). However, an important criticism of this is the contention that, while this is the ideal, often support is dependent on what and who is available (Segrin, 2003).

The informal support systems are made up of three subsystems and are defined by the ranked importance of their relationship to the older person. Thus the primary informal support system consists of kin (family); secondary is friends and neighbours, while tertiary informal support systems (also quasi-formal) are described as being mediating support elements such as religious or cultural organisations (see Table 1 below).

Informal support systems for the older person fall roughly into two broad categories: informal support for the functional, well elderly, and support for the moderately severely impaired (Cantor \& Little, 1985). Support for the functionally well will mainly be drawn from family, friends and neighbours with a high degree of reciprocity taking place. The relationships here are predominately affective, with the older person taking an active part in the family life. Characteristically, a high degree of intergenerational interchange takes place, be it advice, monetary gifts or assisting adult children with child rearing. Table 1 below best illustrates this process.

TABLE 1

THE INFORMAL SUPPORT SYSTEM OF THE OLDER PERSON

\begin{tabular}{|l|l|l|l|}
\hline \multicolumn{1}{|c|}{$\begin{array}{c}\text { Informal } \\
\text { support systems }\end{array}$} & \multicolumn{1}{c|}{$\begin{array}{c}\text { Type of } \\
\text { care }\end{array}$} & \multicolumn{1}{c|}{ Subsystems } & \multicolumn{1}{c|}{ Comment } \\
\hline Primary & $\begin{array}{l}\text { Affective } \\
\text { Instrumental } \\
\text { Personal } \\
\text { care }\end{array}$ & $\begin{array}{l}\text { Spouse } \\
\text { Children } \\
\text { Other relatives }\end{array}$ & $\begin{array}{l}\text { Also referred to as kin. } \\
\text { High incidence of intergenerational } \\
\text { transfer }\end{array}$ \\
\hline Secondary & $\begin{array}{l}\text { Affective } \\
\text { Instrumental }\end{array}$ & $\begin{array}{l}\text { Close friends } \\
\text { Neighbours }\end{array}$ & $\begin{array}{l}\text { Exchange does take place but more } \\
\text { practical and to a lesser degree }\end{array}$ \\
\hline Tertiary & $\begin{array}{l}\text { Affective } \\
\text { Spiritual } \\
\text { Instrumental }\end{array}$ & $\begin{array}{l}\text { Religious affiliations } \\
\text { Community centres }\end{array}$ & $\begin{array}{l}\text { Also referred to as quasi-formal } \\
\text { support systems }\end{array}$ \\
\hline
\end{tabular}

5 A model put forward by Cantor, M. in 1977, in Ageing and Social Care, p.748. 
As can be seen from Table 1, the three subsystems which make up the informal support systems operate in descending order of preference and importance. Consequently, as the older person becomes increasingly frail, as a result of age and/or illness, these relationships undergo a marked shift. The relationship between the older person and family support becomes increasingly unidirectional, i.e. support comes mainly from the family members and the exchange of resources also diminishes (Cantor \& Little, 1985; De Jong Gierveld, De Valk \& Blommesteijn, 2001). It can be seen, then, that in terms of a continuum of care, the older person first draws on support from his or her primary and secondary informal support systems. However, with increased ageing and associated decline in size of the informal support system, the older person will look towards more formalised systems for care support (Cranswick \& Thomas, 2005; Smith, 2000).

The formal support system, on the other hand, is made up of two broad categories or subsystems, viz. (1) political and economic institutions, and (2) voluntary and government organisations (Table 2).

TABLE 2

\section{THE FORMAL SUPPORT SYSTEMS OF THE OLDER PERSON}

\begin{tabular}{|l|l|}
\hline \multicolumn{1}{|c|}{ Formal support systems } & \multicolumn{1}{c|}{ Comment } \\
\hline Political and Economic & $\begin{array}{l}\text { Would determine policies and legislation pertaining to the aged } \\
\text { (e.g. social security) }\end{array}$ \\
\hline $\begin{array}{l}\text { Voluntary and Government } \\
\text { organisations }\end{array}$ & $\begin{array}{l}\text { Concerned with legislative and policy interventions pertaining to } \\
\text { the aged }\end{array}$ \\
\hline
\end{tabular}

The above model as illustrated by Table 2 takes into consideration the bidirectional interaction that takes place between the macro and micro systems, and the effect that these systems have upon one another. Both formal and informal social support networks should be seen as complementary systems, each with its characteristic functions, providing best practice in serving the needs of the older person or what has become known as a task-specific model, or principle of substitution, as conceptualised by Litwak (Cantor \& Little, 1985; Wenger, 1984:195).

\section{Quality-of-life indicators}

From the above it can be seen that the interplay between the informal and the formal support systems are at one at the same time, interdependent and dynamic, operating from the micro to the macro level and working together to hold the older person in a position of stasis. There is no doubt that informal support systems play an enormous role in the care for the aged and so create the conditions that promote quality of life that is central to the concept of active ageing.

While the current emphasis on community living, driven by economic necessity, is supported by WHO's policy framework on active ageing, the development of psycho-sociological models has sought to look at successful ageing in terms of (1) life satisfaction throughout one's life course; (2) social participation and functioning; and (3) inner resources (Bowling \& Dieppe, 2005:1549). However, the active ageing/successful ageing models have failed to take into account the subjective views and objective reality of the older person. Subsequently social scientists began to view these models as limiting in that there was a tendency to negate the very real problems associated with age such as frailty and suffering, especially in the oldest of the old (Baltes \& Mayer, 2001; Cavanaugh, 1997; Lloyd-Sherlock, 2004:6). 
More recently, researchers have begun to move away from focusing on active ageing and to focus on quality-of-life indicators in the older person. ${ }^{6}$ Walker (Kennedy \& Hamilton, 2005:36) suggests that the terms "successful ageing", "positive ageing" and "healthy ageing" are interchangeable and can be used to describe the quality of life of older persons. The study further emphasises that quality of life per se can only be measured by one of two methods: (1) the effect of health on one's quality of life, and (2) subjective interpretation of quality of life. This is clearly in line with the World Health Organisation' definition of quality of life, i.e. "an individual's perception of his or her position in life in the context of the culture and value systems where they live and in relation to their goals, expectations, standards and concerns. It is a broad-ranging concept incorporating ... a person's physical health, psychological state, level of independence, social relationships, personal beliefs and relationship to salient features in the environment" (WHO, 2002:13).

\section{Self-selected quality-of-life indicators in the older person}

In line with the supposition that the older persons' subjective interpretation of QOL as a means of measure is the work undertaken by $\mathrm{GO}^{7}$ the University of Sheffield's programme on the study of quality of life in the older person. This study has proposed a quality-of-life model based on subjective responses from a survey of older people. The themes that came out of this research are in line with the rights and principles of the aged which underpin the policy framework of active ageing (WHO, 2002:13).

Moreover, self-selected quality-of-life indicators that have been identified in several studies can be equated with five of the most identifiable basic needs of the older person (Beaumont \& Kenealy, 2004; Blazer, Sachs-Ericson \& Hybels, 2005; Gabriel \& Bowling, 2004). They are:

- Good social relationships - social support;

- Good home - adequate housing;

- A good neighbourhood - a safe environment;

- Good health and functionality - health;

- Adequate income - economic security.

In addition to the five basic needs of the older person, other quality-of-life indicators that are worth mentioning are having a positive outlook, social activities and hobbies (Beaumont \& Kenealy, 2004:760, 1-14; Blazer et al., 2005:299). The quality of life in the older person is further determined by levels of autonomy and independence, where autonomy refers to the daily and personal decisions one makes about one's life, whilst independence refers to the ability of the individual to undertake daily tasks with the minimum interference or help from others (WHO, 2002:13).

\section{RESEARCH RESULTS}

The main thrust of this paper is the comparison of subjective quality of life indicators across domains that enable members to continue living independently in the community and which serve to anchor the older person within his or her social milieu. To achieve this, factors that impacted on the quality of life of the participants are explored. When asked to rank their quality of life (QOL), the participants were given three options: very good, fair or poor. Fifty-eight

\footnotetext{
${ }^{6}$ The policy framework that was advocated as best practice by the Madrid International Plan of Action on Ageing, 2002.

${ }^{7} \mathrm{GO}$ is an acronym for the Growing Old Programme.
} 
percent (14) ranked their quality of life as very good, while $42 \%$ (10) of the participants ranked their quality of life as fair. No one ranked their quality of life as poor. As the research aimed to explore which factors had influenced the participants choice in ranking their QOL, responses were cross-referenced across various domains.

The more salient points which underpin the determinants of quality of life will be reported in the following sections. They are: factors influencing a good quality of life; migration patterns; home ownership; and the importance of CJSA and religion.

\section{Factors influencing a good quality of life}

All of the participants $(100 \%)$ stated that being healthy, being financially secure and being independent were necessary to having a good quality of life (Table 4) Two thirds of the participants felt that leading an active life was necessary to a good quality of life, while just under two thirds $(62,5 \%)$ felt having hobbies was also important. Of some significance is that five out of seven participants who had no children living in Cape Town ranked their QOL as very good.

TABLE 4

FACTORS INFLUENCING A GOOD QUALITY OF LIFE

\begin{tabular}{|l|c|c|c|}
\cline { 2 - 4 } \multicolumn{1}{c|}{} & Yes & No & Undecided \\
\hline Leading an active life & 16 & 8 & 0 \\
\hline Having hobbies & 15 & 7 & 2 \\
\hline Being healthy & 24 & 0 & 0 \\
\hline Being financially secure & 24 & 0 & 0 \\
\hline Being independent & 24 & 0 & 0 \\
\hline
\end{tabular}

$\mathrm{N}=24$

\section{Migration}

\section{Push/pull factors to current place of residence}

In order to ascertain what were the push/pull factors or migration to the present place of residence, the interviewer asked the participants where they had lived previously, and the reasons for their leaving. In order to cross-reference and verify the responses, similar questions were again asked towards the end of the interview schedule. The three main reasons for moving to (pull factors) the current place of residence were to be with family, to live in a retirement village, and for financial downsizing. Long-distance migration was often precipitated by traumatic life events (push factors).

\section{- Push factors}

Push factors refer to reasons for leaving the area and which result in out-migration. Fifty percent (12) of the participants said they left their previous place of residence to live in the Milnerton area either for business or financial reasons. Of these twelve, 8\% (2) participants retired, $13 \%$ (3) had spouses who retired, and $4 \%$ (1) participant was retrenched. The remaining six participants cited various financial reasons: either it was too expensive to live by themselves $8 \%$ (2), or businesses ventures did not go according to plan - 13\% (3), or downsizing - 4\% (1).

A participant who was unexpectedly retrenched stated: "They gave me the needle. It was a shock. I thought I could go on”. Another participant said: 
- "My spouse was retrenched ... the whites in the 60-65 age bracket ... were top heavy ... thought they would work until 65. My spouse was 62. It was a terrible shock ... my spouse went into deep depression".

The remaining 12 participants cited the following as primary reasons for moving to their current place of residence: Children leaving home totalled 13\% (3); loss of a spouse totalled 13\% (3); health of a spouse/partner totalled $8 \%(2)$; stress totalled $8 \%(2)$ and finally, security scored $8 \%$ (2).

The stress of running a business was such that it precipitated relocation to Cape Town; this is illustrated in the statement given by a participant.

- "The stress of work became too much. So I sold the business and came to live in Cape Town ...."

Of the 24 participants, $50 \%$ (12) of the participants experienced varying degrees of trauma accompanying their relocation. Eight percent (2) moved as a direct result of their spouse's death, while one participant moved in anticipation of their spouse's death. Four percent (1) of the participants moved due to a debilitating disease. Thirteen percent (3) of the participants cited financial reasons, while a further $13 \%$ (3) said it was a result of their children emigrating. Eight percent (2) of the participants who had been mugged said this had a direct bearing on their decision to move to a retirement village.

Twenty-nine percent (7) of the participants relocated from Johannesburg and for some of these members the relocation was a particularly trying and harrowing time.

- "My daughter emigrated and I was left completely alone."

And from another:

- "My spouse knew (s)he was going to die, so we came to Cape Town to be with the children."

- “... it was a terrible wrench".

This participant who made the last statement later stated "Having a new grandchild in Cape Town has filled a void in our lives", which highlights the buffeting effect that the birth of a grandchild has in the face of multiple loss in old age (Clarke \& Roberts, 2004:192).

Four percent (1) of the participants were hijacked whilst living in Johannesburg and this precipitated the decision to move to Cape Town.

\section{- $\quad$ Pull factors}

Pull factors refer to reasons for moving into an area and which result in in-migration. The main reason that the participants gave for moving into their current place of residence was to be near family, i.e. $42 \%$ (10) of the participants. It is significant that $90 \%$ (9 of 10 participants) of this group, relocated from Johannesburg to Cape Town, which translates to $42 \%$ of the total target group. Of these ten, $40 \%$ (4) were widows who moved to be near family and, as already mentioned, one of the participants moved in anticipation of their spouse's death. Three participants were married and two were living with partners.

A further $21 \%$ (5) of the participants moved in order to live in a retirement village. Two of these five participants moved specifically to a retirement village for feelings of safety as a direct result of being mugged. Other reasons given by participants for moving was financial/downsizing $17 \%$ (4); to be near the sea $-13 \%$ (3); and to be near friends $-8 \%$ (2).

- "My aim was always to live in Cape Town. I wanted to live close to my child(ren)." 
- "... I came to Cape Town ... to be near the sea and have a view of the sea!"

While it can be observed that there are two very obvious migration patterns, they do not adhere strictly to the trends observed by a 1988 study by Rogers (as cited by Kinsella \& Velkoff, 2001:55) and the United Nations (UN, 1991b:197). The two migration patterns cited in the literature are: (1) long distance and amenity motivated and (2) short distance and assistance motivated. Although $42 \%$ of the target group migrated from Johannesburg, this was not amenity motivated, but rather to be with family. Moreover, those 14 participants who migrated a short distance, i.e. from within Cape Town, were not necessarily assistance motivated. Just over a third of this group $(36 \%, 5)$, the highest score, were amenity motivated, which contradicts Rogers's observation. Furthermore, there was no evidence to back the observation that the two migration patterns were age-specific, i.e. long distance migration takes place in ones early $60 \mathrm{~s}$, while short distance migration takes place in the 70 to 80 -plus age bands.

\section{Ageing in place}

According to a United Nations report (UN, 1991a:5), there is increasing evidence to suggest that older persons are experiencing higher degrees of migration, also described as the "retirement effect". The same report postulates that ageing in place may also be on the decline. However, this research study showed that $46 \%$ (11) of the participants were born in Cape Town and at present live in Cape Town. Sixty-three percent (15) of the participants have spent most of their adult years in Cape Town, although one of these spent twenty years on the West Coast and just over twenty years in Milnerton. Although 38\% (9) of the participants spent their adult years in Johannesburg, only a third were born in Johannesburg and spent most of their adult life in that city.

Of interest is the fact that all of the participants who fell into the 80-plus age cohort were born in Eastern Europe, either in Lithuania (3) or Latvia (2). One other participant was born in London and was a child evacuee during WW11. Some of the narrative is worth recording:

- "We left in 1932. We managed to get out because we didn't have anything. They were only interested in the wealthy."

- "My parents left in early 1920 ... my uncle was the first person to be shot in the shtetl" (Yiddish for small village - term used in Eastern Europe and Russia).

The research has found no collaborating evidence to support the suggestion that out-migration in early old age is followed by return migration at a later stage ${ }^{8}$ (UN, 1991a:10). Furthermore, the above figures would seem to suggest that ageing in place is not in decline but something that has been enjoyed by just under two thirds of the participants.

\section{Home ownership}

According to the literature (Gabriel \& Bowling, 2004; Windle \& Woods, 2004:584-585), people who owned their own homes experienced a higher degree of quality of life than those who did not, as it was seen to offer the older person a higher degree of emotional security. It has also been observed that it is the immediacy of ownership that has a bearing on one's quality of life and not prior ownership. This is amply illustrated by one participant, who now rents: "I feel I've come down in the world. I'm now renting when (once) I owned two comfortable homes".

As already stated, home ownership has a good deal to do with emotional control over one's environment and thus has a direct bearing on one's quality of life.

\footnotetext{
${ }^{8}$ As was evidenced in Paris, France, where one in three Parisians moved to their place of birth.
} 
Seventy-five percent (12 out of 16 participants) of home owners and $60 \%$ of renters (3 out of 5) rated their quality of life as good. Some responses from the participants who own their own homes and ranked themselves as having a good quality of life are:

- "We're blessed to have our health and house and cars and our own house. We don't have to pay rent. We are financially secure."

- "I am short of nothing: food, a paid-up home. I have family, community and nice people to talk to."

However, none of those who had part ownership said that their quality of life was very good but rather "fair". All three of the participants cited poor health as affecting their quality of life. One participant said:

- "Because I feel I would still like to drive a car, but medically I can't. And be independent and do my own thing."

The above comment serves to highlight the importance of health in the elderly and how ill health impacts negatively on such domains as independence and the sense of control over the environment. What also became apparent was the existence of two distinct groups: the majority of the participants who own their own properties, are on good terms with their neighbours and live in a neighbourhood that is both safe and secure. This group also has a high degree of financial security and a high self-reported quality of life ranking. In sharp contrast to this group is a minority of seniors who do not own their own property, have a lower self-reported qualityof-life ranking, have weaker social ties and less access to public amenities.

\section{Importance of CJSA}

Just over eighty percent of the participants felt that CJSA was important to them. For over half the participants the centre was an important part of their lives. Their narrative gave some indication of the depth of meaning that the participants ascribed to being members of CJSA, Milnerton:

- “It's been a life saver".

- "It's very important to me".

- "It gives me purpose".

A quarter of the participants, while stating that CJSA was important, qualified this by stating that it was more important for other people. Although many of this group did not readily attend the functions at the centre, they all volunteered their services. Two thirds of all the participants volunteered at the centre.

\section{Importance of religion}

Just over half of all the participants attended a place of worship at least once per week, $13 \%$ only attended on special religious days and the remaining $33 \%$ cited "other".

Over half of the participants felt that religion played an important role in their lives and a third of these participants felt that religion was a buffer against trauma such as illness and bereavement. This group also reported that religion had given them a sense of belonging.

"It gives me a sense of belonging ... (you) must have a belief , otherwise you float."

Just under two thirds of all the participants found that religion had become increasingly important to them as they got older. Over half of the participants who rated their quality of life 
as very good also said that religion became more important to them as they aged. Twice as many participants fell into this category than participants who rated their quality of life as fair.

Comparisons of self reported quality of life indicators across domains.

In order to establish a clearer picture between the self-reported "Very Good" and "Fair" quality of life ranking across domains, the researcher examined the percentage makeup of each domain and then ranked the percentage difference, where very good QOL $=14$ participants and fair QOL $=10$ participants (Table 5).

\section{TABLE 5}

\section{COMPARISON BETWEEN SELF REPORTED "VERY GOOD” AND “FAIR" QUALITY OF LIFE RANKING ACROSS DOMAINS ACCORDING TO PERCENTAGE AND RANKED IN PERCENTAGE DIFFERENCE WHERE VERY GOOD QOL = N14 AND FAIR QOL $=$ N10}

\begin{tabular}{|c|l|c|c|c|}
\hline \multicolumn{2}{|c|}{ Rank } & $\begin{array}{c}\text { Very Good } \\
\text { \% } \\
\text { n=14 }\end{array}$ & $\begin{array}{c}\text { Fair } \\
\text { \% } \\
\text { n=10 }\end{array}$ & \% Difference \\
\hline 1 & Very active in organisations & 71 & 10 & 61 \\
\hline 2 & Aged in place & 79 & 30 & 49 \\
\hline 3 & $100 \%$ ownership of property & 86 & 40 & 44 \\
\hline 4 & Being married & 64 & 20 & 37 \\
\hline 5 & Age cohort: 60-69 & 57 & 20 & 33 \\
\hline 6 & Private pension/Investments & 93 & 60 & 31 \\
\hline 7 & Self-ranked perception of health: good & 71 & 40 & 27 \\
\hline 8 & Never lonely & 57 & 30 & 17 \\
\hline 9 & Religion more important with age & 57 & 40 & 16 \\
\hline 10 & Have a strong sense of belonging & 86 & 70 & 16 \\
\hline 11 & No children living in Cape Town & 36 & 20 & -16 \\
\hline 12 & Age cohort: 80 + & 29 & 36 & -21 \\
\hline 13 & Age cohort: 70-79 & 7 & 50 & -24 \\
\hline 14 & Percentage of widows & 36 & -33 \\
\hline 15 & Percentage of State pensions & & \\
\hline
\end{tabular}

The factors that were found to have the highest level of influence in determining a very good quality of life and ranked in accordance to the highest percentage difference are reported below.

1. Being very active in at least one organisation, be it a community centre, religious activities, sports, volunteer organisation or political body (Naleppa \& Reid, 2003).

2. Living most of your adult life in the same city as well as retiring in the same city - in other words, ageing in place. Ageing in place has been seen as typifying many older person (UN, 1991a:5). Just under half of all the participants were born in Cape Town, while just under two thirds of the participants spent most of their adult years in Cape Town.

3. Having $100 \%$ ownership of one's current residential property as opposed to part ownership or renting. This is supported by studies that have shown that home ownership contributed to the older person's sense of wellbeing (Blane, Wiggins, Higgs \& Hyde, 2004; Gabriel \& Bowling, 2004). Furthermore, home ownership allows for a sense of control over one's 
environment and is associated in turn with feelings of security, independence and autonomy (Beaumont \& Kenealy, 2004; Windel \& Woods, 2004).

4. Being married. $64 \%$ of the participants (i.e. 9 out of 14) who ranked their quality of life as very good were married, while only $20 \%$ (2 of the 10) participants who ranked their quality of life as fair, were married. Being married implies both the availability of a primary support system as well as a higher degree of economic well being than for the single or widowed older person (Kinsella \& Velkoff, 2001).

5. Being between the age of 60-69 in other words, young-old. The supposition here is that the younger-old tend to be more financially secure than the older old (Ozawa \& Hong, 2003). The conjecture too is that the younger old have a higher level of functionality than their older counterparts. Younger seniors also tend to volunteer more than their older counterparts and volunteerism, in turn, has a positive influence on QOL ranking (Wan, Odell \& Lewis, 1982). However, this study did not show any really significant age differential with regard to volunteering and QOL ranking (57\% very good QOL vs 50\% fair QOL ranking).

6. Having either a private pension and/investments as opposed to a state pension grant - in other words, being financially independent. Economic security allows for good health. Living in a good home and a good neighbourhood also determines the ability to enjoy good social relationships (Gabriel \& Bowling, 2004).

7. Having the perception of good health. It is not only good health and functionality that influence the older person's quality of life, but also the fact that there is a strong link between subjective health and life satisfaction (Kennedy \& Hamilton, 2005; Lauer, 1989). Seventy-one percent (10/14) of the participants who ranked themselves as having a very good quality of life ranked themselves as having good health.

8. Never being lonely. There were almost twice as many participants who stated that they were never lonely and who ranked their QOL as very good (57\% compared to 30\% who gave a fair QOL ranking). The link between having a sense of belonging and the strength of one's adaptive mechanisms needs further exploration.

9. Have the sense that religion has become more important with ageing.

10. Have a strong sense of belonging.

The three factors that were found to have the most negative impact on the participants' quality of life in order of importance and in descending order are indicated below.

1. State pension grant. Four out of the ten participants who ranked their QOL as fair were state pensioners, while only one in 14 with a very good QOL had a government pension fund (Table 5). The percentage difference score in this instance was minus thirty-three percent $(-33 \%)$.

2. Widowhood. One and a half times more participants who ranked their QOL as fair were widowed. In other words, $60 \%$ or 6 out of the 10 participants who ranked their QOL as fair were widowed. For those who ranked their QOL as very good, only 36\% were widowed (Table 5).

3. Advancing age. The majority of the participants who ranked their quality of life as fair were between 70-79. However, the fact that the 80+ ranked marginally higher than their 70-79 age cohort (Table 5) gives credence to the observation that the oldest old are less likely to complain than their younger counterparts (Fakourie \& Lyon, 2005:6). 
From the above it can be seen that the older persons' sense of security is of paramount importance to their quality of life. Inextricably linked to the feelings of security are financial independence and an intact primary support system, i.e. being married. These two factors in turn enable the older person to have a greater degree of mastery over their environment. The fact that the younger old are more likely to be married also provides an explanation as to why this age group tends to experience a higher quality of life than their counterparts in the 70-79 age bracket.

\section{DISCUSSION}

Counter-intuitively, this study showed that most older persons who have no adult children living in the same city as they do in fact reported a very good quality of life. This would tend to confirm literature studies which state that the depth of the relationship is not contingent upon proximity or frequency of contact, but rather on the quality and density of the relationship (Blane et al., 2004; Hall \& Havens, 2002).

The participants unanimously stated that being independent, financially secure and healthy were all factors that determined a "good" quality of life. However, cross-comparisons of the various domains, using percentage differences, found that the three factors that most determined a very good quality of life were, in descending order of importance: (1) being very active in organisations; (2) ageing in place; and (3) sole ownership of property. Conversely, the factors that would have the most negative impact on the older person's quality of life would be: (1) having a state pension; (2) being a widow; and (3) being in the 70-79 age bracket.

It would seem that these two sets of determinants are interdependent for two reasons. Firstly, financial security allows independence and increases the chances of health and wellbeing. Secondly, ageing in place and active involvement in a civic or religious organisation enhances the older person's sense of belonging. Furthermore, these findings are in line with studies that state that the immediacy of home ownership lends itself to a higher ranking of quality of life and that financial security is a strong indicator for healthy wellbeing in the older person. Conversely, being financially compromised, as in the case of state pensioners, has a deleterious effect on one's self-reported quality of life ranking. It could be argued that government restrictions imposed on state pensioners is a form of economic exclusion. A study by Blazer $e t$ al. (2005) showed that economic exclusion over protracted periods of time led to higher rates of mortality amongst ethnic minorities. It is not known if the same principle would apply to the older person who receives a state pension, which could be a matter of further research.

Active participation in at least one community organisation, be it secular or religious, proved to be the strongest determinant to having a very good quality of life. Not only are community centres effective in extending the social support base of older persons, they are also useful tools in assisting older persons to re-integrate into society after such life events as retirement ${ }^{9}$ and widowhood. Similarly, religious belief and participation in the religious life of a community are key determinants in the quality of life for many older people. Not only do religious beliefs act as an adaptive mechanism in the ageing process, but they also act as a buffer against the multiple losses that are characteristic of this life stage.

Further moderating factors when considering the quality of life of older persons is ageing in place and migrating patterns, central to which are the push/pull factors. Ageing in place acts as a buffer against a diminishing social support system and may account for the high ranking it

\footnotetext{
${ }^{9}$ Or forced retirement in other words retrenchment.
} 
enjoys in determining the older person's quality of life. While most older persons in the study aged in place, a significant percentage of those who moved in order to be near family relocated from Johannesburg. However, while Kinsella and Velkoff (2001:55) see migration patterns of older persons as a means of reuniting family members, the multiple losses that are associated with moving may well cancel any positive effects of being closer to family members.

Social workers who deal with the older person in the Jewish community must be aware that older persons who are at risk and are the most vulnerable will be those who have a self-reported poor quality of life, those who are financially compromised, those who are widowed, and those who are aged 70 and older. Further considerations should focus on seniors who have migrated long distance, where trauma and multiple loss has accompanied such a move, and who do not participate in any community organisation, be it secular or religious.

Moreover, social workers need to be aware that older persons who rent or part-own their property are economically vulnerable, are the most concerned about their financial future, and in almost all instances are state pensioners. They are also more likely to have weaker social ties within the neighbourhood. The role of the social worker in this instance is two-fold. Firstly, it is essential that social workers know what resources are available in both the Jewish community and the community at large so as to best meet the older person's economic needs in terms of providing social relief. Secondly, without encroaching on the older person's rights to self determination, the social worker needs to assist the older person integrate into community centres and/or relevant religious bodies so as to strengthen and expand social ties.

Finally, social workers need to be aware that seniors falling into the oldest-old age group of 80 years and over may have either themselves, or their families and relatives, experienced first hand the ravages of WWII (and in some instances WWI). In the case of Jewish seniors where participants fled as children before war broke out, the participants may carry with them the traumatic memories of their parents. Moreover, social workers need to be aware that memories of past traumatic events experienced during WWII may be triggered by present-day crises and must refer such older persons to professionals who specialise in Post-Traumatic Stress Syndrome.

\section{RECOMMENDATIONS}

Although the population of older persons across all race groups in the Western Cape has increased by 3\% between 1996 and 2001 (Department of Social Development, n.d.:7), the lack of data sets pertaining specifically to the Jewish aged within the South African context gives rise to two areas of concern.

Firstly, while the South African Jewish population has steadily declined, the rate of population ageing of the Jewish population is not known. Certainly the population of Jewish seniors in the Western Cape is considerably higher than comparable age cohorts across the various race groups (Statistics SA, 2001a, 2001d). In the long term this may have implications with respect to old age dependency and parent support ratios. Commenting on the most recent survey of South African Jewry, Kaplan $(2006: 19)^{10}$ noted that the perception has grown that the Jewish community is not an ageing population. This perception may well have an impact on two fronts: (i) it may inadvertently diminish the importance of the role (and future role) that social service organisations play in the lives of Jewish seniors, and (ii) as a consequence hamper access to adequate and equitable funding.

\footnotetext{
${ }^{10}$ In $199865 \%$ agreed and in $200546 \%$ agreed that the Jewish population is not an ageing population.
} 
Secondly, further research is required to study the combined effects of out-migration and decreased replacement levels upon the adult dependency ratio within the Jewish community as this has relevance for long-term planning and policy decisions for Jewish welfare organisations in terms of its older population. To this end, a national survey of the Jewish senior population should be undertaken in order to establish patterns of population growth/decline against the worldwide phenomenon of population ageing. However, this cannot be undertaken unless an accurate census of South Africa's Jewish population is undertaken. ${ }^{11}$

\section{BIBLIOGRAPHY}

BABBIE, E. \& MOUTON, J. 2001. The practice of social research. Cape Town: Oxford University Press.

BABBIE, E. \& MOUTON, J. 2003. The practice of social research. Cape Town: Oxford University Press.

BALTES, P.B. \& MAYER, U.K. 2001. The ageing Berlin study. Ageing from 70 to 100. UK: Cambridge University Press.

BARNHART, C.L. \& BARNHART, R.K. 1987. The world book dictionary (vol 1). Chicago: World Book Inc.

BEAUMONT, J.G. \& KENEALY, P.M. 2004. Quality of life perceptions and social comparisons in healthy old age. Ageing \& Society, 24:755-769.

BLANE, D., WIGGINS, R., HIGGS, P. \& HYDE, M. 2004. Inequalities in quality of life in early old age. Research Findings, 9. From the Growing Older Programme. Economic and Social Research Council. November 2002. Available: http://www.shef.ac.uk/uni/projects/gop/Blane_ F9pdf. [Accessed: 13/12/2005].

BLAZER, D.G., SACHS-ERICSON, N. \& HYBELS, C.F. 2005. Perception of unmet basic needs a $\mathrm{s}$ a predictor of mortality among community dwelling older adults. American Journal of Public Health, 95(2):299-304.

BOWLING, A. \& DIEPPE, P. 2005. What is successful ageing and who should define it? British Medical Journal, 331:1548-1551.

BOWLING, A. 2005. Measuring health. A review of quality of life measurement scales $\left(3^{\text {rd }}\right.$ ed). Berkshire: Open University Press.

CANTOR, M. \& LITTLE, V. 1985. Aging and social care. In: BINSTOCK, R.H. \& SHANAS, E. (eds) Handbook of ageing and the social science $\left(2^{\text {nd }}\right.$ ed $)$. New York: Van Nostrand Reinhold Company.

CARROLL, B. \& WHELAN, T. 1994. Reflections on the Round Table. Positive ageing - the way forward. In: Proceedings of Round Table. Theories of ageing and attitudes to ageing in Ireland. Dr Stevens' Hospital, Dublin. 25 ${ }^{\text {th }}$ March, 1994. National Council for the Elderly. Publication No. 33.

CAVANAUGH, J.C. 1997. Adult development and ageing ( $3^{\text {rd }}$ ed). Pacific Grove, CA: Brooks/Cole Publishing Company.

11 Coupled to the religious count being understated by at least 20\% (Kaplan, 2006) is a reluctance to register with the Jewish Community Central Register. A similar trend has been evidenced in the Jewish community in England (Leeson, 2003). 
CLARKE, L. \& ROBERTS, C. 2004. The meaning of grandparenthood and its contribution to the quality of life of older people. In: WALKER, A. \& HENNESSY, C.H. (eds) Growing older. Quality of life in old age. Berkshire: Open University Press.

CRANSWICK, K. \& THOMAS, D. 2005. Elder care and the complexities of social networks. Canadian Social Trends. Statistics Canada. Catalogue No. 11.008.

DE JONG GIERVELD, J., DE VALK, H. \& BLOMMESTEIJN, M. 2001. Living arrangements of older persons and family support in more developed countries. In: Living arrangements of older person. Special issue No's 42/43. United Nations Population Bulletin. New York: United Nations Publication: 193-217.

DEPARTMENT OF SOCIAL DEVELOPMENT. n.d. South African policy for older persons. Department of Social Development. Republic of South Africa: 6-15.

DONIN, H.H. 1991. To be a Jew. A guide to Jewish observance in contemporary life. Canada: Harper Collins

DUBB, A.A. 1994. The Jewish Population of South Africa. The 1991 Socio-demographic survey. Cape Town: Jewish Publications.

FAKOURI, C. \& LYON, B. 2005. Perceived health and life satisfaction among older adults. The effects of worry and personal variables. Journal of Gerontological Nursing, 31(10):17-24.

GABRIEL, Z. \& BOWLING, A. 2004. Quality of life in old age from the perspectives of older people. In: WALKER, A. \& HENNESSY, C.H. (eds) Growing older. Quality of life in old age. Berkshire: Open University Press.

GRINNELL, R.M. Jr. 1985. Social work research and evaluation $\left(2^{\text {nd }}\right.$ ed). Australia: FE Peacock Publishers.

GRINNELL, R.M. Jr., TUTTY, L. \& WILLIAMS, M. 2005. The quantitative research approach In: GRINNELL, R.M. Jr. \& UNRAU, Y.M. (eds) Social work research and evaluation. Quantitative and qualitative approaches $\left(7^{\text {th }} \mathrm{ed}\right)$. Oxford: Oxford University Press: 86-87.

HALL, M. \& HAVENS, B. 2002. Social isolation and social loneliness. In Writings in Gerontology (18) Mental Health and Ageing, October. National Advisory Council on Ageing. Canada. Available: http://www.naca-centa.ca/writings_gerontology/writ18/writ18_e.htm. [Accessed: 04/02/2006].

HARRIGAN, M.P. \& FARMER, R.L. 2000. The myths and facts of ageing. In: SCHNEIDER, R.L., KROPF, N.P. \& KISOR, A.J. (eds) Gerontological social work $\left(2^{\text {nd }}\right.$ ed). Canada: Wadsworth. Brooks/Cole.

KAPLAN, M. 2006. The future of South African Jewry - comments and observations. Cape Town: University of Cape Town.

KENNEDY, A. \& HAMILTON, S. 2005. The evidence on quality of life for older people. Nursing Times, 10(42):36-37.

KINSELLA, K. \& VELKOFF, V. 2001. An Ageing World: 2001. Bureau of the Census, USA. Series p95/01-1. Washington, DC.: US Government Printing Office.

KOSMIN, B.A., GOLDBERG, J., SHAIN, M. \& BRUK, S. 1999. Jews of the "new South Africa": highlights of the 1998 national survey of South African Jews. JPR Report No. 3 September 1999. Institute for Jewish Policy Research, London. 
LAUER, R.H. 1989. Social problems and the quality of life $\left(4^{\text {th }}\right.$ ed $)$. Dubuque: Wm C. Brown Publishers.

LEGARE, J., IBRAHIMA, M., SOSSA, O. \& SMUGA, O. 2003. Population ageing: a challenge for developing countries. International Federation on ageing. University of Montreal. Available: www.ifa-fw.org/docs/PopulationAgeing20021.doc. [Accessed: 09/10/ 2006].

LLOYD-SHERLOCK, P. 2004. Ageing, development and social protection: generalisations, myths and stereotypes. In: LLOYD-SHERLOCK, P. (ed) Living longer. Ageing, development and social protection. London \& New York: UNRISD Zed Books Ltd.

MINISTRY OF WELFARE AND POPULATION DEVELOPMENT. 1997. White Paper on Social Welfare. Government notice no. 1108, Government Gazette 386 (18166), 8 August, Pretoria: Government Printer.

MINISTRY OF WELFARE AND POPULATION DEVELOPMENT. 2003. Older Persons' Bill. Government Gazette No. 25347, 13 August, Pretoria: Government Printer.

NALEPPA, M.J. \& REID, W.J. 2003. Gerontological social work. A task-centred approach. New York: Columbia University Press.

OZAWA, M.N. \& HONG, B.-E. 2003. Disability and economic well being in old age. Journal of Disability Studies, 13(4):231-243.

QURESHI, H. 1990. Social support. In: PEACE, S.M. (ed) Researching social gerontology. Concepts, methods and issues. London: SAGE Publications: 32-45.

RUBIN, A. \& BABBIE, E. 1993. Research methods for social work ( $2^{\text {nd }}$ ed). Pacific Grove, California: Brooks-Cole.

SEGRIN, C. 2003. Age moderates the relationship between social support and psychosocial problems. Human Communication Research, 29(3):317-342.

SHERIDAN, M.J. \& KISOR, A.J. 2000. The research process and the elderly. In: SCHNEIDER, R.L; KROPF, N.P. \& KISOR, A.J. (eds) Gerontological social work (2 ${ }^{\text {nd }}$ ed). Wadsworth: Brooks/Cole.

SIEBERT, D.C., MUTRAN, E.J. \& REITZES, D. 2000. Friendship and social support. The importance of role identity to ageing adults. In: KEIGHER, S.M., FORTUNE, A.E. \& WITKIN, S.L. (eds) Age and social work. The changing landscapes. Washington, DC: NSAW Press.

SMITH, J.A. 2000. Ontario family councils programme. Research on family councils. Available: http://www.familycouncils.net/2000lit.html. [Accessed: 07/05/2006].

STATISTICS SOUTH AFRICA. 2001a. Census 2001: Age, gender, and population per province. Available: http://www.statssa.gov.za/extract.htm. [Accessed: 25/05/2005].

STATISTICS SOUTH AFRICA. 2001b. Census 2001: Gender, religion and population as per province and district council. Judaism. Available: http://www.statssa. gov.za/extract.htm. [Accessed: 27/05/2005].

STATISTICS SOUTH AFRICA. 2001c. Census 2001 Geography by age for person weighted, Judaism. Space-Time Research Web Page. (Reports produced by Mans, G. 2004 and Mostert, V. 2007). 
STATISTICS SOUTH AFRICA. 2001d. Census 2001: For Jewish faith/Hebrew, person weighted per province per age. Available: http://www.statssa. gov.za/extract.htm. [Accessed: 18.06.2007.

STEIN, Y. 1986. The challenges of meeting the future needs of the elderly in an aging and shrinking Jewish community. Cape Town: South Africa. Rough Draft.

STRYDOM, H. 2005. The pilot study. In: DE VOS, A.S., STRYDOM, H., FOUCHÉ, C.B. \& DELPORT, C.S.L. Research at grass roots - for the social sciences and human service professions $\left(3^{\text {rd }}\right.$ ed). Pretoria: Van Schaik Publishers.

TERRE BLANCHE, M. \& DURRHEIM, K. (eds) 2002. Research in practice. Applied methods for the social sciences. Cape Town: University of Cape Town Press.

UNITED NATIONS (UN). 1991a. Ageing and Urbanisation. Proceedings of the United Nations International Conference on Ageing Populations in the context of Urbanisation. Sendai (Japan), 12-16 September 1988. New York: 5.

UNITED NATIONS (UN). 1991b. UN Secretariat, Population division, Dept of international Economic and Social Affairs Global perspective on population ageing in the context of urbanisation. In Ageing and Urbanisation. Proceedings of the United Nations International Conference on Ageing Populations in the context of Urbanisation. Sendai (Japan), 12-16 September 1988. New York: 55-80.

UNITED NATIONS (UN). 2002. Madrid plan of action on ageing. Report on the Second World Assembly on Ageing 2002. Available: www:http//file://A:IReport of the Second World Assembly on Ageing.htm [Accessed: 10/02/2005].

WAN, T.T.H., ODELL, B.G. \& LEWIS, D.T. 1982. Promotion of well being in the elderly. A community diagnosis. New York: Hawthorne Press.

WENGER, C.G. 1984. The supportive network. Coping with old age. London: George Allen \& Unwin.

WINDLE, G. \& WOODS, R.T. 2004. Variations in subjective wellbeing: the mediating role of psychological resource. Ageing and Society, 24:583-602.

WHO (WORLD HEALTH ORGANISATION). 2000. Information needs for research, policy and action on ageing and older adults in Africa. Report of a workshop on creating a minimum data set for research, policy and action on ageing and the aged in Africa. Harare, Zimbabwe 2022 January 2002. HelpAge International.

WHO (WORLD HEALTH ORGANISATION). 2002. Active ageing: A policy framework. A Contribution to the $2^{\text {nd }}$ UN World Assembly on Ageing, Madrid, Spain, April 2002. Geneva.

WITKIN, S.L. 2000. How ripened are you? In: KEIGHER, S.M., FORTUNE, A.E. \& WITKIN, S.L. (eds) Ageing and social work. Washington, DC: NASW Press: 24.

ZODIKOFF, B. 2003. Understanding older spousal dyads attitudes towards community service use: An analysis of applied theoretical models. Journal of Gerontological Social Work, 39(3):3-31.

Ms Sue Parton, Masters student, Department of Social Work, University of Stellenbosch; Professor Sulina Green, Chairperson, Department of Social Work, University of Stellenbosch, Stellenbosch, South Africa. 